\title{
Correction to: Dissenting Directors
}

\author{
Piergaetano Marchetti $^{1}$ - Gianfranco Siciliano ${ }^{5}$ Marco Ventoruzzo M,2,3,4 $^{1,4}$
}

\section{Correction to: Eur Bus Org Law Rev (2017) 18:659-700 https://doi.org/10.1007/s40804-017-0093-z}

Gianfranco Siciliano's affiliation was incorrect, since Mr. Siciliano is affiliated to the Department of Accounting at the Bocconi University and not to the Bocconi University School of Law.

This mistake happened during the production process of the article and unfortunately remained unnoticed.

The original article can be found online at https://doi.org/10.1007/s40804-017-0093-z.

$\triangle$ Marco Ventoruzzo

marco.ventoruzzo@unibocconi.it

Piergaetano Marchetti

piergaetano.marchetti@unibocconi.it

Gianfranco Siciliano

Gianfranco.siciliano@unibocconi.it

1 Bocconi University School of Law, Milan, Italy

2 Pennsylvania State University Law School, University Park, PA, USA

3 Max Planck Institute, Luxembourg, Luxembourg

4 Research Associate, ECGI, Brussels, Belgium

5 Department of Accounting, Bocconi University, Milan, Italy 